\title{
SOSIALISASI DAN PELATIHAN POB MONITORING SAMPAH LAUT TERDAMPAR BAGI GURU-GURU KIMIA ALUMNI FKIP UNIVERSITAS MATARAM SEKOTA MATARAM DAN SEKITARNYA DALAM RANGKA MENUJU ZERO PLASTIC
}

\author{
Muti’ah $^{1 *}$, Siahaan Jeckson', Agus Abhi Purwoko', Mukhtar Haris', Supriadi' \\ ${ }^{1}$ Program Studi Pendidikan Kimia, Universitas Mataram, Mataram, Indonesia. \\ * Coressponding Author. E-mail: mutiah_fkip@unram.ac.id
}

\begin{abstract}
Received: 29 Agustus 2021 Accepted: 4 Februari 2022 Published: 6 Februari 2022
\end{abstract}
\begin{abstract}
Abstrak
Kegiatan ini bertujuan untuk memberikan sosialisasi dan pelatihan POB monitoring sampah laut terdampar bagi guru-ruru kimia dalam rangka menuju zero plastic. Untuk mencapai tujuan tersebut telah dilakukan kegiatan: sosialisasi secara daring, pendampingan/praktek pengambilan dan pengukuran jumlah sampah, dan evaluasi. Hasil yang diperoleh dari kegiatan ini adalah sebagai berikut: (1) Kegiatan sosialisasi dan praktek pengumpulan dan identifikasi sampah di lokasi Pantai Batas Senja Mapak Mataram telah berjalan dengan baik dan peserta menunjukan perhatian yang cukup tinggi, (2) Hasil praktek pengumpulan dan pengukuran jumlah serta berat sampah dihasilkan 4 jenis sampah yaitu plastik, kayu, logam, dan karet. Untuk sampah plastik mendominasi jumlah dan beratnya yaitu 170 item dengan berat $1050 \mathrm{gr} / 50 \mathrm{~m}^{2}$. (3) Hasil analisis sampah plastik didapatkan bahwa $63,9 \%$ berasal dari bungkus makanan/ jajanan atau minuman dan $36,1 \%$ berasal barang kegiatan masyarakat. (4) Dari hasil respon kegiatan ini di dapatkan bahwa semua peserta menyatakan siap menjadi pendekar/srikandi "sampah" di sekolah masing masing. Kesimpulan dari kegiatan adalah adanya kesadaran yang tinggi dari para guru untuk mengedukasi siswanya tentang bahaya dan cara mengurangi sampah plastik menuju zero plastic setelah mengikuti kegiatan.
\end{abstract}

Kata Kunci: sampah laut terdampar, zero plastic, pelatihan monitaring sampah

\section{PENDAHULUAN}

Secara umum, sampah laut yang terdampar di pantai dapat dikategorikan berdasarkan ukuran dan jenis materialnya. Untuk kegiatan ini, ukuran sampah yang relevan untuk dikumpulkan dengan mempertimbangkan alat yang digunakan adalah sampah laut terdampar dalam ukuran makro dan mega. Berdasarkan jenis materialnya (chemically), sampah laut terdampar di pantai diklasifikasikan ke dalam 6 kategori (berdasar adaptasi klasifikasi NOAA) (2013), yaitu: (1) plastik dan karet, (2) logam, (3) kaca, (4) kayu, bukan kayu alami seperti ranting pohon yang jatuh secara alamiah, dan lain-lain, (5) pakaian dan sejenisnya, (6) sampah lainnya.

Faktanya, produksi material plastik tampak tak terbendung dari waktu ke waktu. Keadaan ini diperparah lagi dengan perilaku masyarakat yang boros dalam penggunaan plastik sekali pakai. Polusi sampah plastik memapar tak hanya daerah urban, tetapi juga mencapai pelosok kampung, taman nasional, hingga pesisir pantai di tempat terpencil di Indonesia. Masalah ini menjadi semakin kritis karena tidak diterapkannya metode 3R/4R dalam mengatasi masalah sampah plastik. Bisa dikatakan bahwa kegiatan daur ulang (recycle) baik yang dilakukan masyarakat maupun pemerintah tidak sebanding dengan produksi material-material berbahan plastik yang terus meningkat.

Menurut NOAA (National Oceanic and Atmospheric Administration) sampah laut didefinisikan sebagai benda padat persisten yang diproduksi atau diproses oleh manusia, baik secara langsung maupun tidak langsung, baik secara sengaja maupun secara tidak sengaja, yang dibuang atau ditinggalkan di lingkungan laut. Berbagai tipe sampah laut dapat kita temukan setiap hari di perairan laut, misalnya plastik, kain, busa, styrofoam (gabus), kaca, keramik, logam, kertas, karet, dan kayu. Berbagai ukuran sampah laut juga kita temukan di perairan laut termasuk di pantai, mulai dari ukuran yang besar 
(megadebris dan makrodebris hingga mikro/nano debris) yang keduanya dapat menimbulkan resiko yang sangat berbahaya bagi kesehatan mahluk hidup secara langsung terutama bagi hewan laut seperti ikan, penyu dan penyu laut, dan burungburung dikarenakan salah konsumsi atau karena kena jeratan, yang kesemuanya ini dapat menyebabkan pendarahan internal dan bisul, serta penyumbatan saluran pernafasan dan pencernaan bahkan kematian bagi biota laut.

Jambek et al., (2015) dari universitas Georgia mengatakan Indonesia merupakan produsen sampah plastik ke laut terbesar kedua setelah Cina. Sementara itu, (Lebreton et al., 2017) mengatakan bahwa sampah plastik di laut didominasi sampah plastik yang berasal dari sungai. Mengacu pada asumsi Kementerian Lingkungan Hidup (KLH), setiap hari orang Indonesia menghasilkan $0,8 \mathrm{~kg}$ sampah termasuk sampah plastik atau kalau kita totalkan ada sejumlah 189 ribu ton sampah per hari. Sebagian dari total sampah ini dibuang langsung ke perairan dan akhirnya berada di laut. Hasil penelitian Jambek et al., (2015) yang dimuat dalam Jurnal Science (2015), Indonesia hampir tidak mengolah limbah plastiknya sama sekali. Dari 3,8 juta ton sampah plastik, 3,2 juta ton berakhir di laut setiap tahunnya. Sementara itu, studi oleh Program Lingkungan PBB (UNEP) tahun 2015 menyebutkan dunia memproduksi 280 juta ton plastik untuk berbagai keperluan, dari jumlah ini hanya sedikit yang didaur ulang.

Sementara beberapa senyawa kimia yang ditemukan terbukti berbahaya untuk kesehatan manusia. Kandungan kimia ini umumnya masuk melalui makanan, atau air yang terkontaminasi. Makanan merupakan objek yang paling sering terpapar plastik. Mulai dari kemasan makanan plastik, hingga menyantap makanan panas di wadah plastik. Menurut studi terbaru yang diterbitkan oleh Environmental Pollution, lebih dari 100 bagian kecil dari partikel plastik yang disebut sebagai mikroplastik ditemukan dalam setiap makanan.

Berdasarkan latar belakang di atas maka dapat diidentifikasi permasalahan adalah sebagai berikut: (1) Sampah laut terdampar banyak ditemukan di pantai batas senja mapak mataram (2) Ketidakpedulian masyarakat terhadap sampah plastik, (3) Penanganan sampah memerlukan partisipasi aktif individu dan kelompok masyarakat. (4) Posisi guru kimia sangat strategis untuk menyebar-luaskan hal-hal tentang sampah laut dan permasalahannya dari perspektif kimia.

Solusi yang relevan dengan permasalahan di atas adalah: memberikan pemahaman dan pelatihan yang lebih komprehensif tentang sampah plastik dari perspektif kimia, masalah dan bahayanya, dan cara mengatasinya

Manfaat yang diperoleh dari kegiatan ini adalah sebagai berikut: (1) Dengan mensosialisasikan bahaya sampah plastik bagi kehidupan dan POB dalam kajian tentang sampah laut (marine debris) diharapkan para guru bisa menjadi penggerak dalam mengatasi masalah sampah plastik ini. (2) Dengan adanya kegiatan ini diharapkan posisi guru kimia menjadi sangat strategis untuk menyebar-luaskan hal-hal tentang sampah laut dan permasalahannya dari perspektif kimia.

\section{METODE PELAKSANAAN}

Metode pelaksanaan program pengabdian kepada masyarakat ini adalah berupa sosialisasi dengan pemberian materi kuliah (2 sesi) tentang sampah plastik dengan seluruh permasalahannya yang dilaksanakan secara daring dan sekali praktek lapangan (tentu dengan Prokes yang ketat). Sementara itu, kajian lapangan dilakukan dalam beberapa tahap, antara lain:

\section{(1). Survey}

Dalam kegiatan ini, dilakukan pengamatan sampah terdampar di pantai dengan mengadaptasi metode Shoreline Survey Methodology berdasarkan NOAA (2013). Sebelum melakukan pengamatan sampah laut yang terdampar di pantai ada beberapa hal penting yang harus disiapkan seperti pemilihan lokasi pengamatan, bahan dan alat yang diperlukan pada pengamatan dan waktu pengamatan. Pemilihan lokasi pengamatan di tentukan di pantai Batas Senja Mapak Mataram.

\section{(2). Pengamatan Dan Praktek Lapangan}

Praktek lapangan dilakukan dengan mengumpulkan semua sampah yang terlihat dan bersihkan dari pasir/lumpur/air, mimbang berat total semua sampah $(\mathrm{kg})$ dan langsung diklasifikasi, dihitung jumlah dan ditimbang beratnya (berat basah)

\section{HASIL KEGIATAN}

\section{Sosialisasi Melalui Kuliah daring}

Kegiatan sosialisasi merupakan kegiatan dengan tujuan utama memberi pengetahuan 
tentang bahayannya sampah dan dampak negatif yang diberikan terutama kepada kehidupan pesisir pantai, hal ini sesuai dengan hasil kegiatan sosialisai yang dilaporkan oleh sukib et al., (2019). Sosialisasi terutama terkait dengan bahaya sampah plastik, cara menjaga kebersihan pantai dan cara pengukuran jumlah dan berat sampah. Sosialisasi tersebut diberikan secara daring mengingat saat ini sedang dalam masa pandemi covid-19. Edukasi yang diberikan juga tentang bahaya sampah plastik yang bisa bersifat genetik terhadap mahluk hidup (manusia, hewan dan tanaman). Hasil kegiatan menunjukan bahwa guru guru terlihat tertarik memeperhatikan apa yang disampaikan oleh tim. Beberapa bukti keseriusan peserta dalam kegiatan ini mereka ditunjukkan dari hasil angket di akhir kegiatan semua peserta memberikan respon menjadi lebih paham tentang

a. Sampah terdampar di pantai dan terminologi tentang ukurannya, terutama sampah plastik dan konsep chemilcally undegradable,

b. Penyebab masalah sampah, khususnya sampah plastik di lingkungan laut maupun di sekitarnya,

c. Dampak sampah plastik bagi lingkungan laut, darat dan udara,

d. Kerugian secara environmental yang ditimbulkan sampah khususnya sampah plastik.

e. Pentingnya mengedukasi masyarakat terutama murid-murid tentang dampak dan bahaya sampah khususnya sampah plastik

Keseriusan peserta juga ditunjukkan bahwa semua peserta siap untuk menjadi pendekar/srikandi "sampah" dengan melibatkan murid-murid dan masyarakat sekitar.

\section{Praktek Lapangan Pengamatan Sampah Terdampar di Pantai \\ Dalam Kegiatan ini Tim menjelaska mengapa lokasi pantai Batas Senja Mapak Mataram yang menjadi sasaran dalam pengumpulan sampah terdampar dan cara membuat transek lokasi. Pelaksanaan kegiatan ini ditunjukan oleh gambar 1 berikut.}

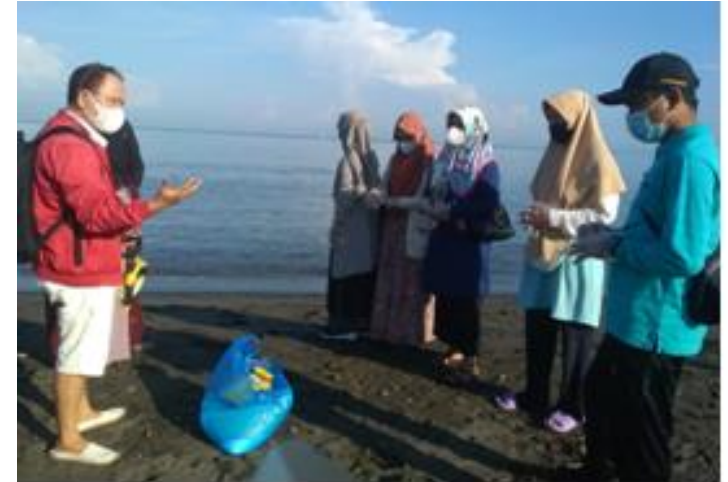

Gambar 1 Situasi saat penjelasan dan pengamatan langsung lokasi pantai

Berdasarkan gambar di atas tim menjelaskan mengapa pantai Batas Senja menjadi sasaran pemilihan lokasi. Hal ini dijelaskan karena pantai tersebut memenuhi karakteristik yang disarankan yaitu:

a. kemiringan antara $15-45^{\circ}$ dan berpasir

b. Pantai mudah dijangkau dan langsung menghadap lautan

c. Pantainya jauh dari pelabuhan atau penahan gelombang

d. Pantainya terlihat jelas batas pasang surutnya

e. Tidak ada kegiatan pembersihan pantai secara regular

Selanjutnya salah satu tim menjelaskan cara menentukan area pengambilan sampah adalah sebagai berikut:

a. Pembuatan transek garis sepanjang $2 \times 25$ meter atau langsung 50 meter, lebar sepanjang 1 meter ke arah laut dan 1 meter kea rah daratan.

b. Pengumpulan sampah laut terdampar dilakukan dengan berjalan kaki sepanjang garis transek.

\section{Praktek Pengumpulan dan identifikasi Sampah}

Kegiatan praktek pengumpulan/ pemungutan sampah dilakukan setelah para peserta yang telah mengikuti sosialisasi, sehingga mereka dapat mengklasifikasi sampah tersebut dengan baik. Pelaksanaan kediatan ditunjukkan pada gambar 2. 


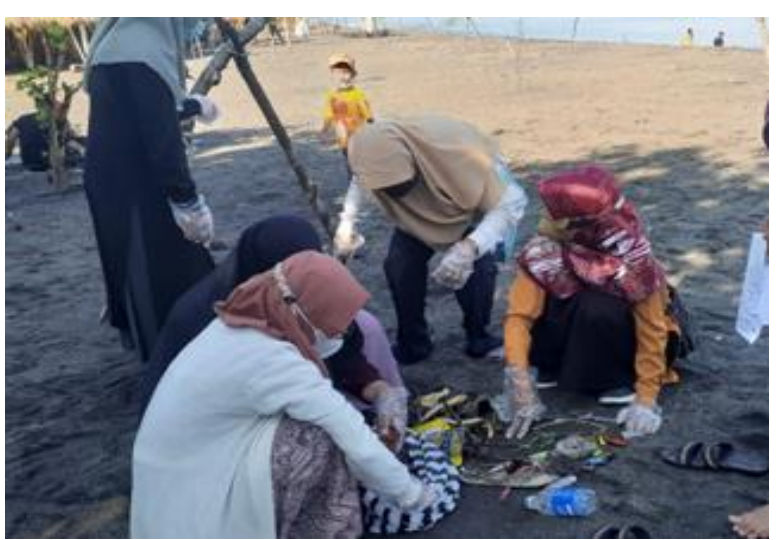

Gambar 2. Kegiatan pengumplan dan identifikasi jenis sampah

Hasil sampah setelah dipungut selanjutnya dikumpulkan untuk dapat diidentifikasi dan ditimbang secara langsung. Kegiatan penimbangan dan identifikasi langsung setiap pengambilan sampah ditunjukkan seperti gambar 3 berikut.

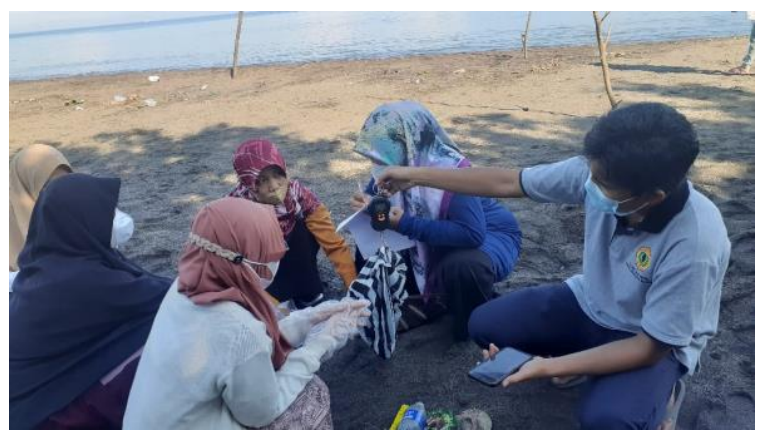

Gambar 3 Penimbangan sampah

Selanjtnya sampah diidentifikasi menurut jenis kelompoknya seperti plastik, karet, logam , kayu dan lainnya. Setiap jenis masih harus diidentifikasi untuk mendapatkan gambaran polutan yang terbanyak sehinga dapat dijadikan acuan dalam pengolahan amaupun menanggulangannya. Hasil analisis menggunakan jenis dan berat ditunjukkan pada tabel 1 berikut.

Tabel 1 Hasil Analisis Sampah Terdampar di

\begin{tabular}{lllll}
\multicolumn{5}{c}{ Pantai Batas Senja } \\
\hline No & $\begin{array}{l}\text { Kelompok } \\
\text { Sampah }\end{array}$ & Kuantitas & jenis & $\begin{array}{l}\text { Berat } \\
(\mathrm{g})\end{array}$ \\
\hline 1 & Plastik & 170 & 17 & 1050 \\
2 & Karet & 4 & 2 & 350 \\
3 & Logam & 5 & 3 & 100 \\
4 & Kayu & 4 & 2 & 1150 \\
\multicolumn{5}{c}{ Total Berat sampah } \\
\hline
\end{tabular}

Berdasarkan tabel di atas menunjukkan bahwa berat sampah plastik mendominasi pada kelompok sampah pantai terdampar, kemudian kayu, karet dan logam. Sampah plastik menunjukkan 17 jenis dengan jumlah 170, sedangkan untuh sampah lainnya hanya 2-3 jenis dengan kuantitas 4-5. Jumlah total berat sampah di dapatkan $2600 \mathrm{gr}$, dengan rincian sampah plastik 1050gr, karet 350gr, logam 100gr, dan kayu 1150 gr. Hal ini sesuai dengan yang diungkapkan oleh Lebreton et al., (2017) dan Muti'ah et al., (2019) bahwa sampah plastik di laut didominasi sampah plastik. Sampah jenis plastik juga mendominasi kuantitas dan beratnya. Hasil tersebut juga menunjukkan bahwa belum adanya kepedulian masyarakat akan bahayanya sampah plastik di lautan. Untuk dapat mengetahui bagaimana pola jenis sampah plastik yang mendominasi selama pengambilan, disajikan dalam tabel 2 berikut.

Tabel 2 Hasil Identifikasi Sampah Plastik Terdampat di Pantai Batas Senja

\begin{tabular}{|c|c|c|c|c|}
\hline $\begin{array}{l}\mathrm{N} \\
\mathrm{O}\end{array}$ & $\begin{array}{l}\text { Kelompo } \\
\text { k Plastik }\end{array}$ & $\begin{array}{l}\text { kuanti } \\
\text { tas }\end{array}$ & sumber & $\%$ \\
\hline 1 & $\begin{array}{l}\text { Sacet } \\
\text { minuman }\end{array}$ & 34 & $\begin{array}{l}\text { Jajanan } \\
\text { anak }\end{array}$ & \\
\hline 2 & / snack & 24 & Jajanan & 62,9 \\
\hline 3 & $\begin{array}{l}\text { Bungkus } \\
\text { sosis }\end{array}$ & 20 & $\begin{array}{l}\text { anak } \\
\text { Jajanan }\end{array}$ & \\
\hline 4 & Botol & 19 & anak & \\
\hline 5 & Sendok & 10 & Minuman & \\
\hline 6 & Tali rafia & 10 & Makanan & \\
\hline 7 & $\begin{array}{l}\text { Bungkus } \\
\text { obat }\end{array}$ & 10 & $\begin{array}{l}\text { Lainnya } \\
\text { Lainnya }\end{array}$ & 36,1 \\
\hline 8 & $\begin{array}{l}\text { Stiroform } \\
\text { Lainnya } \\
\text { (10 jenis) }\end{array}$ & $(1-3)$ & lainnya & \\
\hline
\end{tabular}

Berdasarkan tabel 2 diatas menunjukkan bahwa jenis saset minuman dan snack mendominasi jumlahnya diikuti oleh bungkus sosis, botol, bungkus obat, tali rafia, sendok dan stirofom. Berdasarkan jenisnya maka dapat di perkirakan jenis tersebut merupakan samapah plastik berasal dari rumah tangga yang terbawa aliran sungai. Hal ini sesuai dengan asumsi Kementerian Lingkungan Hidup dan Kehutanan (KLHK) (2018), bahwa sebagian dari total sampah masyarakat dibuang langsung ke perairan dan akhirnya berada di laut. Sampah di laut $80 \%$ berasal dari daratan dan sisanya berasal dari transportasi laut. Hasil analisa menunjukkan bahwa banyakanya sampah palstik tersebut berasal dari makan jajanan anak dan minuman. Disini perlunya guru untuk mengedukasi masyarakat terutama murid-murid tentang 
dampak dan bahaya membuang sampah plastik sembarangan dan bagaimana mengurangi jumlah sampah plastik. Berdasarkan tabel 6.2 maka edukasi dari guru diharapkan dapat mengurangi sampah plastik terdampar secara signifikan mengingat dari banyaknya sampah plastik berasal dari makanan anak anak dan minuman mencapai $62,9 \%$ dan lainnya ( barang kegiatan masyarakat) adalah $36,1 \%$.

\section{KESIMPULAN DAN SARAN}

\section{Kesimpulan}

Kesimpulan dari kegiatan ini adalah sebagai berikut: (1) Kegiatan sosialisasi dan praktek pengumpulan dan identifikasi sampah di lokasi Pantai Batas Senja Mapak Mataram telah berjalan dengan baik dan peserta menunjukan perhatian yang cukup tinggi, (2) Hasil praktek pengumpulan, serta pengukuran jumlah dan berat sampah didapatkan 4 jenis sampah yaitu plastik, kayu, logam, dan karet. Untuk sampah plastik diurutan pertama didapatkan 170 item dengan berat $1050 \mathrm{gr} / 50 \mathrm{~m}^{2}$. (3) Hasil analisis sampah plastik didapatkan bahwa $63,9 \%$ berasal dari bungkus makanan/ jajanan atau minuman dan $36,1 \%$ berasal barang kegiatan masyarakat. (4) Dari hasil respon kegiatan ini di dapatkan bahwa semua peserta menyatakan siap menjadi pendekar/srikandi "sampah" di sekolah masing masing.

\section{Saran}

Saran yang disampaikan dalam kegiatan ini adalah perlu kegiatan berkelanjutan bagi guru guru yang telah menjadi pendekar/srikandi "sampah".

\section{DAFTAR PUSTAKA}

Andrady, A.L., 2003. Plastics and the environment, In: Anthony L. Andrady (Ed.),
Publisher: John Wiley and Sons, ISBN 0-47109520-6.

https://ekonomi.bisnis.com/read/20181122/99/8 62486/klhk-sampah-di-laut-sebagianbesar-dari-daratan. 22 November 2018

Jambeck, J. (2015). Plastic Waste inputs from Land Into Ocean. . Climate Change 2014: Impacts, Adaptation and Vulnerability, 347 (January), 1655-1732.

Lebreton, L. v.-W. (2017). River Plastic Emissions to the World's Oceans. . Nature Communications, 8, , 15611.

National Oceanic and Atmospheric Administration. (2013). Programmatic Environmental Assessement (PEA) for the NOAA Marine Debris Program (MDP). Maryland (US): NOAA.

Marojahan, R. (2015). Hubungan Pengetahuan Masyarakat Tentang Sampah Dengan Perilaku Mengelola Sampah Rumah Tangga Di Rt 02 Dan Rt 03 Kampung Garapan Desa Tanjung Pasir Kecamatan Teluk Naga Kabupaten Tangerang. Forum Ilmiah Volume 12 Nomor 1, 33-44.

Muti'ah, et al., (2019). Sosialisasi dan Pendampingan Masyarakat Pesisir Tentang Cara Menjaga Kebersihan Pantai dan Cara Pengukuran Jumlah Sampah. Jurnal Pendidikan dan Pengabdian Masyarakat Vol. 2 No. 1, Februari 2019 $(141-146)$

Sukib et al., (2019). Meningkatkan Kesadaran Bahaya Sampah Laut Melalui Pendampingan pada Masyarakat Lokasi Wisata Pantai Kuranji ., Jurnal Pengabdian Magister Pendidikan IPA (JPMPI). (2) 2. pp. 102-106 